\title{
Two Cultures versus General Education
}

\author{
JOH N R. D A VID \\ T.H. Chan School of Public Health, Harvard University, Boston, MA, USA. \\ Email: jdavid@hsph.harvard.edu
}

\begin{abstract}
On reading C.P. Snow's 'The Two Cultures and The Scientific Revolution', I was struck by the deep split he describes between scientists and literary intellectuals. One cause he proposes is the age-old specialization of English education, where each of the two cultures has long been segmented into rigidly defined subcultures. I came to learn about UK specialization in the 1980s in Brazil when I mentored a student for his Masters degree based on a study of leishmaniasis and its insect vector, the sand fly. When the student later went to England for his $\mathrm{PhD}$, he was not required to learn about any other parasites - or other any other vectors - to pass his examinations. A different story from what would have happened at the Harvard School of Public Health where, for his $\mathrm{PhD}$, he would have taken a variety of courses and been examined on all the parasites infecting humans as well as all the other insect vectors, not just sand flies.
\end{abstract}

\section{A General Education}

I'd say that education in the US is much less specialized. I went to the University of Chicago under Chancellor Hutchins in 1947, where after a preliminary week of exams, the path to a BA consisted of courses the faculty thought one needed for a general education. There were no electives, but courses in philosophy, history, humanities, languages, social and natural sciences and mathematics/logic (all taught with primary papers, no textbooks). The students were not split into the usual divisions such as Freshman, Sophomore, Junior and Senior, but were all in one group. Around $80 \%$ were Second World War veterans, the rest were a naïve bunch, like me. There was one lecture and three seminars a week. You were not required to go to class and everything depended on a 6 hour exam at the end of the term in June. But because you had professors such as David Riesman of The Lonely Crowd fame (this was before he went to Harvard) and C. Wright Mills, who wrote The Power Elite, I eagerly went to several seminars covering the same course. The aim of the University of Chicago college was to teach one to read and to become a knowledgeable citizen.

'Freedom of speech' at the University of Chicago in the 1940s and 1950s was quite different from the 'political correctness' now evident in colleges and universities 
today. Chancellor Hutchins railed against Joseph McCarthy and there were certainly no required loyalty oaths at $\mathrm{U}$ of $\mathrm{C}$ as there were at some of the Ivy Colleges/Universities. But, more important, in addition to non-controversial speakers such as Reinhold Niebuhr and Jawaharlal Nehru, we also heard Hans Eisler, a leftist composer considered a Communist (but never a party member). We also heard the extreme right-wing journalist Westbrook Pegler, who made a living railing against FDR/New Deal legislation, the Supreme Court, and labour unions, and who later agitated for the John Birch Society. His writing, always a Cold War screed, became exceedingly shrill in the 1950s and 1960s. Nevertheless, Pegler, Eisler, et al. were allowed to speak: there was never any heckling. Ann Coulter would have been listened to, unlike the protests in 2017 at the University of California Berkley. Freedom of speech meant you let people talk even if you strongly disagreed with them.

\section{Continuing Education}

I was also amazed by C.P. Snow's report that in the course of his Civil Service career he and his team had interviewed over 30,000 scientists and found that they had not read any books except, perhaps, Charles Dickens. Not me!

During my whole scientific career, reading novels, non-fiction and poetry (I especially loved Fernando Pessoa) was a guilty pleasure - I was doing that instead of reading science journals. It was a guilt not present when attending concerts or plays. Indeed, that guilty pleasure continues to this day. When it comes to fiction, one of the high points for me was a summer in Woods Hole when I read 11 of Faulkner's novels, now my favourite American author. As to history, A Peace to End all Peace by David Fromkin and The Kings Depart by Richard M. Watt were especially impressive. Talleyrand, A Biography by J.P. Bernard was quite illuminating, as this brilliant man, loved by the ladies (indeed he had a mistress when he was a bishop), turned out not the double-dealing horror I had been taught in history classes, He was able to keep himself alive in a most troubled time and everything he did served to keep the peace. Love and Capital by Mary Gabriel gave fascinating insights into Karl Marx's life, who was literally kept alive by Engels. When it comes to music, it has taken the place of religion in my life. I play the piano and my present 'priestess', a young Spanish cellist/composer who is also a pianist, gives me lessons; these have greatly added to my life. Furthermore, our apartment is filled with paintings, many by Brazilian painters, obtained over the past 20 years when my wife, Roberta, and I spent two months a year carrying out research on parasitic disease in Salvador de Bahia. So when it comes to me, the two cultures of science and art are very much intertwined, as they are for many of my scientific colleagues.

I did not know many authors, personally, just three. As a teenager, I met Aldous Huxley, who was quite familiar with science. The other two authors, Lewis Thomas and Gerald Weissmann, were primarily scientists. But my closest contact with creative writing was through my father, Charles David, who, among other talents, was a screenwriter. Through him, I met a number of other screenwriters who may - or may have not - have known much science. Before this, my father had been CEO of Pathé 
in Paris at the age of 24 and produced Drole de Drame, also known as Bizarre Bizzare, which became a classic. Against considerable opposition, my father hired Jacques Prévert to write the screenplay. (In return, Prévert taught me how to pronounce French obscenities.) The film had some of the greatest stars of the period, including Françoise Rosay, Michel Simon, Louis Jouvet, Jean-Louis Barrault (playing a vegetarian serial killer of butchers) and Jean-Pierre Aumont. In 1939 my father produced the desert part of The Four Feathers for Alexander Korda in Sudan, and later, in Hollywood, directed Lady on a Train with Deanna Durbin.

C.P. Snow made a point of mentioning how pure scientists look down upon applied scientists. I was reminded of my own evolution, which began with basic science studies on the mechanisms of cellular immunity, which led to a recognition of the central role that lymphocytes play in immunology. I then moved from basic studies in cell and molecular biology to address more practical problems. These studies yielded diagnostic monoclonal antibodies for various species of Leishmania; and - since the dog is the animal vector of transmission in this zoonosis - deltamethrineimpregnated dog collars to prevent the transmission of visceral leishmaniasis. We also came up with radio-wave induced heat therapy for cutaneous leishmaniasis, which can be done in five minutes and replaces the standard therapy with age-old, toxic drugs, which must be given for three weeks. These applied scientific efforts were at least as satisfying as my contributions to basic biology.

\section{On to Artificial Intelligence}

I am struck that the dangers C.P. Snow perceived in 1959 are similar to those we face in 2017, more than half a century later: the threats of nuclear wars, an exploding world population, and the gap between rich and poor (although now I think he might have also added Climate Change). Daily, we see the effects of global warming: hurricanes that are becoming more severe cause major flooding throughout the globe, but also droughts that decimate farm lands, especially in Africa. Loss of tillable land is a major cause of the mass migration of Africans to Europe, with devastating social and political effects on both continents.

In his fourth lecture, C.P. Snow discusses the rich and poor, warning that the industrial nations are getting richer, whereas the non-industrial nations are at best standing still. Remaining poor, the people in these nations eat less and live shorter lives. Since he wrote this in 1959, some of the non-industrial countries have discovered some natural resources, such as oil, or valuable minerals, but only a dismally few people have become fabulously rich, the majority remain destitute. To help industrialize these countries in Africa and Asia, Snow suggests, requires an abundance of new capital and many thousands of engineers. He argues these could only come from the developed nations such as the USA, Western Europe and the Soviet Union; Snow thought that the Soviets would be more likely to provide these resources if we did not. He was sure that capital must come from nations; it could not come from the private sector. His lectures were given at the time of the Cold War, when the Soviet Union was considered a major power, not the present Russia, which is 
strapped economically. He realized that the solution he proposed was possibly utopian, but considered that the world cannot continue with this rich/poor divide. $\mathrm{He}$ also answered sceptics by stating that scientists have the right attitude to accomplish this as 'They are freer than most people from racial feelings; their own culture is in its human relations a democratic one.' I wish he were right.

Since he gave his lecture, several countries such as China have become much more industrialized, and have, for instance, established a rapid train system covering the longest distances in the world. The terrible pollution in cities such as Beijing and Delhi is the result of their industrialization. Brazil has had a solution to extreme poverty by giving poor families subsidies and free health care. When I visited favelas (slums) in Brazil, I was amazed that parents would show me the booklet that proved that their children had all been vaccinated, something that was necessary for school attendance,

C.P. Snow correctly stated that, 'In fact, the two revolutions, the agricultural and the industrial-scientific, are the only qualitative changes in social living that men have ever known.' The Industrial Revolution was known for creating numerous jobs. People left the rural farming areas and came to cities where the jobs were in factories. Should he have given his lectures in 2017, he might have brought up the probable third major qualitative change in social living, namely the future Technology Age of Artificial Intelligence and Robots, killing jobs and introducing whole new problems, such as how to obtain the funds needed for the many people who cannot join the disappearing workforce. That will be a bigger problem than his 'Two cultures'.

\section{About the Author}

John David is the Richard Pearson Strong Professor of Tropical Public Health, Emeritus at the T.H. Chan School of Public Health at Harvard. He has applied his major discovery of a molecule that mediates cellular immunity - MIF - to diseases such as leishmaniasis that ravage underdeveloped countries. 